\title{
Elizaveta V.Ivanova
}

St. Petersburg State University,

7-9, Universitetskaya nab., St. Petersburg, 199034, Russia

e.v.ivanova@spbu.ru

\section{On the basic lines of proverbial studies in Russian paremiology*}

For citation: Ivanova E. V. On the basic lines of proverbial studies in Russian paremiology. Vestnik of Saint Petersburg University. Language and Literature. 2021, 18 (4): 875-892.

https://doi.org/10.21638/spbu09.2021.415

The article summarises the principal achievements of domestic scholars in the area of proverbial studies, important both for the research on Russian proverbs and the analysis of proverbs in other languages. An important contribution was made by the introduction of the concept of the paremiological level of language and the detailed description of structural and semantic proverbial characteristics of a typological and specific nature, as well as the analysis of the similarities and differences between proverbs and phraseological word-combinations. Great significance can be attributed to the studies of the proverbial fund as a system and the introduction of the concept of the proverbial space, which permitted researchers to consider proverbs within a multi-dimensional continuum. An important line of research was the study of the pragmatic functions of proverbs and the proverbial variations, manifested in discourse and text, along with the experimental research into the knowledge and usage of proverbs by native speakers. Extensive theoretical and practical skills in the lexicographic presentation of proverbs, resulting in the compilation of numerous dictionaries, deserve special attention. The tradition of examining proverbs in the context of culture, and the results of studies on proverbial semantics in general, laid the foundation for cognitive and cultural-and-linguistic approaches to proverbial research, which have been developing significantly during the past twenty years, giving new dimensions to cross-linguistic proverbial studies.

Keywords: proverb, paremiology, proverbial semantics, proverbial fund.

\section{Introduction}

The article is aimed at a survey of the most significant lines of research pursued by Soviet and Russian scholars, engaged in the study of proverbs, as well as important contributions made both to the analysis of Russian proverbs and the development of theoretical foundations of this area of paremiology in general.

The Soviet and Russian tradition of proverbial studies was based on the works of their predecessors dating back to the $19^{\text {th }}$ - beginning of the $20^{\text {th }}$ century. The research done by F. I. Buslaev, V. I. Dal', A. F. Potebnia, I. M. Snegirev and other scholars, focusing on the practice and theory of proverbial description and systematisation, laid the foundation for

* The reported study was funded by Russian Foundation for Basic Research (RFBR), project number 20-112-50028.

(C) St. Petersburg State University, 2021 
many lines of proverbial studies, which have been and still are successfully and fruitfully developing.

In the years before World War II only some studies stand out, among which it is possible to mention the works by I. E. Anichkov [Anichkov 1992] and M. A. Rybnikova [Rybnikova 1961]. However, the second half of the $20^{\text {th }}$ century, especially its last thirty years, witnessed a real heyday of Russian paremiology, connected with the works of V.P. Anikin [Anikin 1996], V. A. Arkhangel'skii [Arkhangel'skii 1964], V.P.Zhukov [Zhukov 1991], Yu. I. Levin [Levin 1984], V.M. Mokienko [Mokienko 1975; 1986], G. L. Permiakov [Permiakov 1970; 1975], Z. K. Tarlanov [Tarlanov 1982], V.N. Teliia [Teliia 1996] and their followers. The range of the problems, fundamental for the study of proverbs in any language, included the issue of the linguistic status of the proverb, its double nature as a language sign or text, the distinct features of its analysis within the framework of linguistics and folklore, the structure of the proverbial fund and many others. Russian paremiology has been always targeted at both the typological characteristic features of proverbs and their specific features, typical of a certain language. This makes the results of domestic studies valuable for proverbial research in any language.

In the $20^{\text {th }}$ century according to the domineering areas of linguistic research, proverbs were analysed from the aspect of structural linguistics, semiotics, onomasiology, semantics and pragmatics. At the turn of the $21^{\text {st }}$ century, the shift of the research paradigm resulted in the studies based on cognitive and cultural linguistics.

The diversified and multifaceted exploration of proverbs, based on new paradigms and simultaneously taking into account the achievements of the preceding generations of scholars, has continued in the $21^{\text {st }}$ century and is represented by the works of V.I. Zimin [Zimin 2017], D. O. Dobrovol'skij [Dobrovol'skij 2017], E. V. Ivanova [Ivanova 2002], M. Yu. Kotova [Kotova 2004], O. V.Lomakina [Lomakina 2016], L. B. Savenkova [Savenkova 2002], E. I. Seliverstova [Seliverstova 2017], N. N. Semenenko [Semenenko 2011] and many others.

In the current article it is not possible to name all Russian paremiologists and list all the worthy results of their work. The survey is focused only on the most important theoretical statements, which had a lasting impact on the development of paremiology, and the most promising lines of proverbial analysis, systematisation and description.

\section{Definition of a proverb, its linguistic status and basic characteristics}

An important trait of Russian proverbial studies consists in identifying a proverb as a language unit on the basis of its comparison with other similar units along a number of parameters. This allowed the scholars to outline categorical and differentiating proverbial features and to streamline the material included into the proverbial fund.

In their definition of the linguistic status of the proverb, Russian scholars considered its basic structural and semantic characteristics, allowing for a certain range of their variety, stipulated by the continuity of the language system and the gradual shift from one language characteristic to another. Despite the inevitability of this variety, their efforts were aimed at the delineation of valid and convincing criteria for differentiating a proverb from other language structures that had similar characteristics in many aspects.

The basic structural characteristic of the proverb by which it differs from many set, reproduced and idiomatic language units is its linguistic status as a complete sentence. 
Proverbial sentences were considered clichéd predicative structures, unsusceptible to any arbitrary change in their components, but nevertheless allowing for a certain lexical and grammatical variation [Zhukov 1991; Levin 1984; Permiakov 1970; Tarlanov 1982]. Numerous dictionaries of proverbs of Russian or other languages traditionally include language units that do not have the structure of a complete sentence. As a result this differentiating structural characteristic of the proverb proved to have theoretical and practical value.

Inherent semantic proverbial features embraced a generalized meaning [Levin 1984; Permiakov 1970; Tarlanov 1993], its aphoristic and instructive character [Kotova 2004; Kunin 1996; Tarlanov 1993; Shadrin 1991] and imagery, normally dependent on metaphor [Permiakov 1970: Tarlanov 1993].

The question of the proverb belonging to linguistic signs or texts inevitably arose in connection with defining its linguistic nature. Back in the 1920s, Anichkov stated that the proverb was the shortest genre of literature, immediately preceding the fable, but belonging both to the sphere of literature and to the sphere of language [Anichkov 1992: 141]. Permiakov believed the proverb had a triple nature, considering it first as a language phenomenon, second - as a logical unit, third - as an artistic miniature [Permiakov 1970: 8]. The scholar assumed that as a linguistic sign the proverb was the object of linguistics and as a text - the object of folklore.

The text has semiotic functions, so the issue in question did not concern the viability of the semiotic status of the proverb, but the viability of its status as a linguistic sign, and hence the plausibility of the application of the research apparatus for linguistic signs towards it. V.V.Gvozdev considered the proverb the most complicated structure that could be granted the status of a linguistic sign [Gvozdev 1983: 13]. Kotova regarded only frequently used proverbs as linguistic signs, denying this status to those not in common usage. [Kotova 2004: 176]. N. N. Amosova totally excluded proverbs from the language system, seeing them as self-sufficient units of communication [Amosova 1963: 145].

Considering the controversial nature of the proverb, Permiakov placed it on a special language level - paremiological [Permiakov 1975: 250-251]. The introduction of this level meant an innovative approach because it outlined a considerable group of units (according to Permiakov, more than 24), characterized by certain common structural, semantic and functional properties, and at the same time different from each other by a number of other structural, semantic and functional parameters. The concept of the paremiological level had a significant impact on Russian proverbial studies, but it did not solve the problem of including or excluding proverbs from phraseology.

\section{Proverbs as units of paremiology and phraseology}

The problem of the borders of phraseology was not considered in foreign linguistics because the latter addressed phraseological issues in general quite late. In Russian linguistics this problem, concerning a wide or narrow concept of phraseology, was solved in two ways. Thus, Arkhangel'skii [Arkhangel'skii 1964], A. V. Kunin [Kunin 1996], T.Z.Cherdantseva [Cherdantseva 1977] and N.M.Shanskii [Shanskii 1985] regarded proverbs as part of phraseology, while Amosova [Amosova 1963], Zhukov [Zhukov 1991] and A. I. Molotkov [Molotkov 1977] excluded them from phraseological units. Such proverbial characteristics as idiomaticity, imagery, figurative meaning and stability of the gram- 
matical form during a substantial period of time justified their inclusion into phraseology [Gaevaia 1990:6]. Proverbial characteristics preventing their unification with phraseological word-combinations encompassed the underlying statement and the ability of a proverb to be an independent unit of communication, as well as the possibility of using a proverb in its literal sense, which is totally unacceptable for any phraseological word-combinations [Amosova 1963: 143-145; Zhukov 1991: 9-10; Molotkov 1977: 22].

At present, this problem does not have a clear-cut solution and remains open. In consequence, D. O. Dobrovol'skii assumes that, in theory, proverbs could be ranked as part of phraseology and considered as phraseological units with a sentence structure; in practice, paremiology is an independent area of humanities [Dobrovol'skii 2017: 196, 199]. Lomakina considers paremiology as a section of phraseology [Lomakina 2016: 8-9] and A.I.Gaevaia writes about the paremiological level of phraseology [Gaevaia 1990: 12]. Kotova regards paremiology as an independent area of linguistic research, the object of which is paremias in current usage (proverbs, folk aphorisms, tongue twisters etc.) [Kotova 2004: 176].

The arguments of Russian scholars supporting or denying the relevancy of including proverbs into phraseology have demonstrated the multifaceted and controversial nature of proverbial characteristics, their difference from those of phraseological units and simultaneously the close connection of proverbs and phraseological word-combinations.

\section{Proverbs and sayings}

In separating proverbs from the other constituents of the paremiological level, the basic difficulty lies in the differentiation of proverbs and sayings, which are frequently integrated both by researchers and dictionary compilers in view of the number of common features. Drawing a border between the proverb and the riddle, the proverb and the aphorism, or any other paremiological unit is regulated by structural, semantic, functional and genetic characteristics of these units. The saying has the most uncertain and vague status among the paremias due to the scholarly differences in its definition, which inevitably results in the broadening or narrowing of the proverbial fund. ${ }^{1}$

Permiakov drew the line between the proverb and the saying according to the formal, structural criterion. From his standpoint, the proverb is a complete, clichéd structure (Мал золотник, да дорог / lit. "A ten-rouble coin is small, but valuable"). On the other hand, the saying is an incomplete structure, which undergoes contextual change or addition of components (Стреляет из пушки по воробьям - Он/Она/Петр стреляет из пушки по воробъям / "... shoots sparrows with a cannon" 2 - He/she/Peter shoots sparrows with a cannon) [Permiakov 1970: 9]. Furthermore, Permiakov considered metaphor to be an integral proverbial characteristic, while ranking clichéd sentences with a literal meaning as folk aphorisms: Щи да каша - пища наша / "Cabbage soup and porridge are our food" [Permiakov 1975: 266]. Likewise, Levin based the differentiation between proverbs and sayings on the structural criterion, defining sayings as incomplete predicative structures with a contextual variety of components [Levin 1984].

${ }^{1}$ The term "proverbial fund", denoting the whole collection of proverbs in a language, is widely used in Russian proverbial studies.

${ }^{2}$ In Russian, unlike English, grammatical structures with the verb-predicate in a finite form, but without a subject, are feasible. 
Zhukov chose the semantic parameter as differentiating. The scholar defined proverbs as fixed folk statements with a figurative or figurative and literal meaning (Горбатого могила исправит / "A hunchback will be fixed by his grave"; Чем бы дитя ни тешилось, лишь бы не плакало / "It does not matter what the child plays with, what matters is that the child does not cry"), and sayings - as fixed folk statements with a literal meaning (Коса - девичья краса / "A plait beautifies a maiden"). The scholar also described proverb-and-saying sentences, combining the characteristics of proverbs and sayings and having some components in the figurative meaning, and some - in the literal (На сердитых воду возят / "The angry carry the water") [Zhukov 1991: 11-12]. Incomplete structures like глаза на лоб лезут (у кого-либо) / "sb's eyes are going onto his forehead" were classified as phraseological units by Zhukov [Zhukov 1991:10].

In this way, in Zhukov's classification the structural criterion of a complete sentence lies at the base of differentiating proverbs and phraseological units, but not proverbs and sayings. Molotkov also classifies structures of the tyре вожжа под хвост попала (комуmo) / "the rein got under the tail of sb", as verbal-propositional phraseological units [Molotkov1977: 143]. Following Zhukov, Gaevaia differentiates proverbs and sayings as imagery and non-imagery predicative structures [Gaevaia 1990: 7].

Tarlanov describes the proverb as a brief instructive sentence with a figurative meaning and a generalizing function [Tarlanov 1993: 167, 174]. The saying in his view can also be a sentence, but it is identifiable with a synonym, can include components of concrete, demonstrative semantics, and allows for the usage of verbs in the past indefinite [Tarlanov 1993: 174]. Mokienko regards the saying as a linguistic term synonymous with the term "phraseological unit" [Mokienko 2010: 10].

An important parameter for defining the proverb and differentiating it from the saying is the general or non-general meaning of the language structure under investigation. For Permiakov, the opposition "general/non-general" does not constitute the basis for differentiation, however it does supply an additional characteristic to the units, differentiated according to the structural criterion. Thus, all sayings and some proverbs belong to nongeneral sentences, but general sentences are represented only by proverbs, and never by sayings (Permiakov 1970: 10).

Levin's approach to describing general and non-general proverbs is in tune with that of Permiakov's. As the scholar states, the proverbs Нашла коса на камень / "The scythe has run against a stone" could be applied only to individual, particular situations and do not fulfil the function of generalizing. In this respect, they differ from the sayings (Из-за деревьев леса не видит / "... does not see the forest for the trees") only as far as syntax is concerned [Levin 1984: 119].

E.M. Vereshchagin and V.G. Kostomarov affirmed that sayings, though referring to typical situations, had a concrete or particular meaning, and formed a "bridge" between phraseological units and proverbs [Vereshchagin, Kostomarov 1990: 7].

N.L.Shadrin considered the aphoristic quality - the expression of a general complete thought in a brief form - as a differentiating feature of proverbs [Shadrin 1991: 62-64]. Zhukov asserted that all the three types of units in his classification (proverbs, sayings and proverb-and-saying sentences) could relate either to particular or generalized statements [Zhukov 1991: 11-12]. Tarlanov, on the contrary, regarded the generalizing function as the differentiating proverbial feature [Tarlanov 1993: 174]. 
In some later research works, clichéd sentences with a literal meaning were ranked as proverbs [Zimin 2017; Ivanova 2002; Kotova 2004; Mokienko 2010].

Russian scholars working with foreign languages built their classifications based on the principal provisions of paremiology and the specific features of a language. Thus, L I. Shvydkaia used the semantic differentiating criterion for English proverbs, the border between proverbs and sayings being determined by the opposition "general - non-general" [Shvydkaia 1973: 6].

In the studies of English proverbs, the differentiating structural criterion of Permiakov and Levin could be applicable with some reservations due to the analytic nature of the English language. The obligatory presence of the subject in the sentence a priori excludes the existence of incomplete predicative structures, classified as sayings in Russian. By adhering to structural criterion it is possible to delineate sentences with a varying subject or an attribute to the subject as sayings: His (her, your, Peter's) geese are all swans. He (she, Nick) has two stomachs to eat and one to work [Ivanova 2002: 31].

As follows from the above, Russian scholars have applied three types of parameters (completeness/incompleteness of the predicative structure; figurative/literal meaning; generalizing/non-generalizing meaning) to classify fixed and reproducible sentences, similar with regard to their structural and semantic properties. The primary importance of the research along these lines was not determining a strict border between proverbs and sayings, as this depends on the scholars' views and can vary. The most important outcome was the detailed outline of similarities and differences between large groups of language units, which resulted in complex classifications and descriptions of these groups. It also made it possible to apply with a certain degree of adaptation the same principles of analysis to paremiological units of other languages.

\section{Proverbial semantics}

Russian researchers determined largely the same components in the semantics of the proverb, designated at times with different terms according to the views and concepts of the researcher. The three basic components comprise: the meaning of the proverb (signification/invariant meaning), inner form (image/imagery component/literary meaning/ denotative meaning/etymology) and contextual meaning (referential meaning/concrete situational meaning). Levin defined the meaning of the proverb as the contents that could be expressed with the help of metalanguage, excluding the language and imagery characteristics. The contextual meaning was termed by the scholar as the referential meaning of the proverb, which in his opinion depended on the situation much more than the meaning of the word [Levin 1984: 109-110].

An important concept for the analysis of the proverbial meaning is the generality or normality quantifier, used by Levin and T. M. Nikolaeva to identify the generalizing meaning of the structure under consideration [Levin 1984: 120-125; Nikolaeva 1995: 314]. As a rule, proverbs state some common law, so the components всякий (ая)/объино/every/ normally can be added to their structure: Новая метла чисто метет $\rightarrow$ Всякая/Объцно новая метла чисто метет / "A new broom sweeps clean" $\rightarrow$ "Every/Normally a new broom sweeps clean".

Gvozdev singled out two types of proverbial meaning: invariant and concrete situational. The invariant type is formed on the basis of a number of concrete situational 
meanings, which are the realization of the invariant meaning in the act of communication and correspond to Levin's understanding of the contextual meaning [Gvozdev 1983: 4, 7].

The concept of the proverbial inner form was used by Zimin [Zimin 2017: 55, 64], Ivanova [Ivanova 2002: 34-39], Kunin [Kunin 1996: 87], Mokienko [Mokienko 2010] and other researchers. The studies of the inner form as a semantic category are closely connected with the examination of the components constituting the proverb, its syntax, and logical and semiotic structure. Zimin and Kotova noted the possibility of the idiom inclusion into the proverb [Zimin 2017; Kotova 2004]. This is evident with the example of the proverb Чужую беду руками разведу, а к своей ума не приложу / "I can deal with another's trouble with both hands, but I can't use my mind to cope with my own" which includes the idiom ума не приложить / "use one's mind" [Zimin 2017: 58]. The complex manner of interaction between the phraseological unit and the proverb, and the possibility of the former to precede the latter, was highlighted by Mokienko [Mokienko 2010: 12-13]. Describing the componential composition of the proverb, Seliverstova introduced the concept of the binome to designate a set combination of two words, typical of a number of proverbs and reflecting the patterns of lexical combinations in proverbial structures [Seliverstova 2017: 259, 262].

\section{Proverbial fund as a system}

The efforts of Russian scholars were directed not only at the study of the properties of the proverb as such, but at the analysis of the whole collection of proverbs in a language, called the proverbial fund. The important contribution of Russian scholars lies in the establishment and description of the systematic character of the proverbial fund.

Permiakov considered the paremiological fund as a balanced and consecutive system, stating that the list of its constituents was open to new ones, but as far as typology was concerned it had to be acknowledged as closed, for there was no way to find a constituent whose structure would not conform with the system [Permiakov 1975: 266]. The scholar distinguished four logical-semiotic variants of proverbs based on the situations relating to them, ultimately subdividing these variants into types, then - subtypes. [Permiakov 1970: 20]. Apart from the logical-semiotic taxonomy, Permiakov put forward a classification according to the proverbial features, grouped around a limited number of invariant oppositions, such as "far - near", "kind - evil", "big — small", etc. [Permiakov 1970: 30]. Such principles of systematisation of proverbs are relevant for the vast majority of languages.

The concept of proverbial space introduced by Levin was of vital importance for systematising the proverbial fund [Levin 1984: 108-109]. The scholar approached the concept of space from the aspect of mathematics, selecting two of its types for the analysis of proverbs - topological and metrical. This approach allowed him to establish the property of many dimensions, inherent to the proverbial space and explained by the fact that proverbs relate to each other in various respects (dimensions) according to various parameters. The property of many dimensions resulted not only from the categorical differences of the types of proverbial proximity (meaning, linguistic form, components, etc.), but also from the fact that the very proximity of meanings is manifested along different semantic lines [Levin 1984: 114]. Thus, the proverbial space was defined as a multi-dimensional continuum with a varying density [Levin 1984: 115], the multi-dimensional property differ- 
entiating the proverbial space from the semantic field, which stipulates the consideration of its constituents only in one plane.

The concept of the proverbial space was later elaborated on by many researchers, e.g., by Yu. V. Nikolaeva [Nikolaeva 2000] and Seliverstova [Seliverstova 2017]. Seliverstova described the proverbial space as a system with a complex structure, characterized by stability and variety, and based not only on the paradigmatic relations between proverbs, but on the codes, motives, and patterned fragments [Seliverstova 2017].

Levin's concept of the proverbial space was also in many ways the predecessor of the cognitive approach to proverbs, which emerged at the turn of this century [cf. Ivanova 2002; Semenenko 2011]

\section{Paradigmatic relations in the proverbial fund}

Paradigmatic relations in the proverbial fund are reduced primarily to polysemantic, homonymic, synonymic and antonymic relations, as well as to those between the variants of one proverb. The description of these relations depended to a great extent on the prevailing understanding of linguistic categories underlying them. Thus, the absence of reliable criteria to draw the line between polysemy and homonymy, which allowed Yu. D. Apresian to state the relativity of these linguistic notions and put forward the idea of different degrees of polysemy and homonymy [Apresian 1974: 184-185], inevitably had its impact on the definition of those phenomena in proverbial studies. Researchers divided proverbs into polysemantic and homonymic on the strength of their own view of the principles of that differentiation. Permiakov, for example, assumed that polysemy was relevant only diachronically, while synchronous research was not expected to make any difference between the two phenomena as they both were opposed to synonymy: one sign with several meanings manifests homonymy, several signs with one meaning - synonymy [Permyakov 1974: 942]. Permiakov also described homonymy between different types of paremias, e.g. between a proverb and a legal saying (Лежачего не бъют / "Не who lies on the ground should not be beaten" - a legal saying in the literal meaning and a proverb in its metaphorical meaning) [Permiakov 1975: 264]. Contemporary researchers Kotova and O.V. Raina tend to consider the semantic connection between meanings as the criterion for polysemy [Kotova, Raina 2020].

Levin regarded the absence of an obvious semantic connection as the manifestation of homonymy [Levin 1984: 115]. Gvozdev defined polysemy on the basis of the dichotomy "language - speech": the invariant meaning belongs to a virtual proverbial sign and the concrete situational meaning is realized in speech [Gvozdev 1983: 7-8]. Hence in his opinion, polysemy is a phenomenon of speech, not language.

The variety of the approach to the proverbial polysemy and homonymy for the reasons explained by Apresian does not diminish the significance of the thorough exploration of the dynamic interaction between proverbial meanings and the specifics of their types.

Other types and subtypes of systematic relations in the proverbial fund were also revealed by Russian scholars. Levin, e.g., analysed various cases of synonymous, quasi-synonymous, antonymous and quasi-antonymous relations [Levin 1984: 111-114]. Though not being able to cover all the subtleties of these relations, discovered by the author, we would like nevertheless to draw attention to one of his conclusions concerning the possibility of coordination between the components and the logical or/and language structure 
without any similarity of meanings [Levin 1984: 114]. The illustrating examples (Bcяא кулик свое болото хвалит / "Every sandpiper praises his swamp"; Всяк кулик в своем болоте велик / "Every sandpiper is great in his swamp"), in our opinion, demonstrate another paradigmatic relation in the multi-dimensional proverbial fund. This relation shows the importance of set images in the formation of a proverb, hence their belonging to certain imagery patterns of the proverbial vision of the world, which deserves a detailed investigation.

Levin also elaborated a thorough systematisation of the potential variability of Russian proverbs [Levin 1984: 110-111], applicable to the proverbs of other languages. Mokienko pointed out that the current formation of anti-proverbs in Russian and other languages enlarges the dynamic variability of traditional proverbs [Mokienko 2010: 13].

The antonyms and synonyms of Russian proverbs of the paremiological minimum and their Slavic parallels were scrupulously described by Kotova and Raina [Kotova, Raina 2020].

Hence, it is possible to conclude that Russian scholars have laid the foundations and outlined the directions of the research on the systematic organization of the proverbial fund in any language.

\section{Proverbial fund in sociohistorical, psychological and cultural context}

Considerable significance can be attributed to the Russian studies of sociohistorical, psychological, cultural and cognitive conditions involved in the formation and usage of proverbs.

S. E. Nikitina notes that profound dependence on the community's opinion was typical of peasantry, because due to the traditional way of life in the peasant commune, the personality was not separated from the society in the peasant culture. Folk texts (proverbs, in particular) strengthened that dependence, providing a communal assessment to every event [Nikitina 1989: 35].

Not only social and historical conditions, but psychological factors have their due impact on the formation and functioning of proverbs. T. M. Nikolaeva emphasised the fear of a person of being left out of society and the important illusion of having a homogenous social space behind oneself, creating the belief that one's opinion coincides with the opinion of the crowd [Nikolaeva 1995: 311]. Proverbs offer a person the experience checked by many generations, helping him to find directions in the social space and choose proper solutions to the encountered problems [Zimin 2017: 54; Ivanova 2006: 91; Nikolaeva 1995: 311]. Defined by Nikolaeva as a pragmatic tool, proverbs allow people to delete the individual features of an event, incorporating it into the long row of analogies [Nikolaeva 1995: 311] and thus easing the interpretation of the situation. These properties, inherent to proverbs in any language, exist within the framework of certain cultures, which has its effect on proverbial semantics.

Russian paremiologists thoroughly explored the connection between proverbs and culture, based on the cumulative function of language, i. e., the function of storing the results of cognition and knowledge of the material and spiritual culture in linguistic signs [Vereshchagin, Kostomarov 1990: 15; Teliia 1996: 226]. This largely laid the foundations for cognitive and linguistic-and-cultural proverbial studies in the $21^{\text {st }}$ century. 
V.N. Teliia described proverbs as the language of everyday culture, transferred from one generation to another and reflecting the life philosophy of the people [Teliia 1996: 241]. The scholar defined proverbs as one of the most important cultural codes, owing to their prescriptive nature [Teliia 1996: 218-219]. Researchers indicated that the nation's world vision and interpretation in the context of cultural traditions was fixed in the language, including proverbs [Teliia 1996: 231], the usage of proverbs implying not only the exchange of information, but also the exchange of cultural landmarks and viewpoints [Kovshova 1999: 170]. These statements about the relationship between proverbs and culture are relevant for the proverbial analysis in any language.

There are numerous studies of Russian proverbs in the context of culture [Savenkova 2002; Seliverstova 2017; Tarlanov 1982, and others]. An impressive contribution in this respect was made by Mokienko, who explored the imagery and motives of Russian proverbs based on Russian culture and lifestyle [Mokienko 1986].

\section{Cross-linguistic analysis of proverbs}

Russian scholars also defined the principles of the cross-linguistic analysis of proverbs and carried out diverse proverbial studies along these lines.

Permiakov observed that proverbs of different nations, modelling the same or much similar situations, were very close to each other despite their specific ethnic, geographical, historical or linguistic features [Permiakov 1970: 20]. The difference between proverbs of different languages, in his opinion, primarily concerns the imagery and the cultural components [Permiakov 1970: 29]. It is interesting that in this connection Permiakov mentions differences in the language "model of the world" [Permiakov 1970: 20], foreseeing in a way the descriptions of the proverbial picture of the world and its separate fragments thirty-forty years later.

Levin described the paremiological paradox, the essence of which lies in the fact that, on the one hand, proverbs express the national character, the "soul of the nation", but on the other, the meaning of the majority of proverbs can be referred to as universal, resulting in the existence of proverbial synonymy among languages [Levin 1984: 123].

Anikin divided the cases of coincidence among proverbs of different languages into those resulting from borrowing and those resulting from typological similarity [Anikin 1996]. The scholar emphasised that the similarity stipulated by borrowing was closely connected with the numerous cases of colloquial change, as happened, e.g., when folk proverbs were formed on the basis of Greek proverbial aphorisms [Anikin 1996: 368-370]. Typological similarity in its own right is independent coincidence, based on the resemblance of the mode of life and traditions [Anikin 1996: 370, 378; Mokienko 1975: 83]. At the same time, scholars emphasized that similar proverbs of different nations tend to have their own shades of meaning [Anikin 1996: 371] , and every nation has its own endemic proverbs [Levin 1984: 122].

On the whole, these scholars invariably accentuated that in the cross-linguistic analysis of proverbs it is necessary to take into account the interconnection and interaction of different cultures. With reference to this, Mokienko rightfully indicates that it is difficult to find the exact boundary between your own and foreign culture [Mokienko 1986: 18].

These fundamental principles of cross-linguistic analysis, taking into consideration the mutual permeation of proverbial funds of various languages and their specific cul- 
tural and linguistic characteristics, laid the foundations for many cross-linguistic studies of proverbs. Among illustrating examples of such case studies dating from different years and based on different research paradigms, it is possible to mention those undertaken by Gvozdev on Russian and French proverbs [Gvozdev 1983], E. F. Arsenteva, Ivanova - on English and Russian [Arsent'eva 1989; Ivanova 2002], Kotova - on Russian and Slavic [Kotova 2004], and Yu. V. Nikolaeva - on Italian and Spanish [Nikolaeva 2000].

\section{Functioning in text and discourse}

Proverbial usage studies were focused on the pragmatic functions of proverbs in the text and discourse, the dependence of those functions on the genre, the analysis of the contextual transformations of proverbs and the interaction of the semantic components of the proverb in the context.

Permiakov outlined seven pragmatic functions of paremias: modelling, instructing, predicting, magic, negative-communicative, entertaining and ornamental [Permiakov 1975: 255-259]. The scholar pointed out that each type of paremias had its own domineering and optional functions. Hence proverbs tend to realize modelling and instructing functions, but sometimes they may fulfil others, e.g., prediction (Hет дыма без огня / "There is no smoke without fire") [Permiakov 1975: 255-259]. The modelling function consists in the ability of the proverb to be not only the sign of various life situations, but also the tool for modelling various stereotypical situations [Permiakov 1975: 251]. This definition was important for the subsequent determination and description of cognitive, psychological and sociohistorical reasons for resorting to a proverb.

Dobrovol'skij pointed out the proverbial functions of generalization, recommendation and explanation [Dobrovol'skij 2017: 196-198].

Levin focused on the mechanism of proverbial nomination. While building a model of the contextual usage of the proverb, the scholar presumed the interaction of three semantic layers:

- the literal meaning of the proverb;

- its basic meaning, related to the pattern of the situation;

- the contextual concrete meaning, belonging to the sphere of speech, while the other two belong to the sphere of language [Levin 1984: 119].

Apart from general descriptions of the regularities in the usage of proverbs, there are works on their functions in texts of various genres.

Gaevaia and Gvosdev explored diverse forms of the interaction between proverbs and fiction texts, and the stylistic devices for transforming proverbs [Gaevaia 1990; Gvozdev 1983]. Both researchers stated the disruption of the "external" semantic coordination between the proverb and the text [Gaevaia 1990: 4; Gvozdev 1983: 5]. Lomakina described the wide range of proverbs, employed by L.N.Tolstoy, and demonstrated the formal, judgmental and conceptual devices of explicating the communicative intention in their contextual usage [Lomakina 2016]. E. S. Syshchikova studied the perlocutionary effect of proverbs and sayings in newspaper texts [Syshchikova 2007]. S. V.Sidorkov analysed the role played by proverbs in everyday discourse and literary texts [Sidorkov 2003].

The corpus research of proverbs, gaining a wider scope nowadays [Nikolaeva; Potapova 2018], enables researchers to acquire new data about the functioning of proverbs 
in various contexts. N. A. Potapova, for example, studied Russian paremias, proverbs in particular, with the lexeme камень / "stone" in literary, journalistic, science fiction and colloquial texts of the $19^{\text {th }}-$ beginning of the $20^{\text {th }}$ century. The scholar based her research on the Russian Language National Corpus and analysed the proverbial functions and transformations in the corpus-aggregated texts [Potapova 2018].

\section{Paremiography}

Lexicographic or paremiographic principles of presenting proverbs in dictionaries and reference books did not escape the attention of Russian scholars either. It is quite justified to say that the basic ways, employed by the compilers to arrange proverbs in a dictionary, are listing them in the alphabetic order, by thematic and lexical classification, or by their logical pattern [Gaevaia 1990: 8]. The main difficulty consists in giving an adequate definition of the proverbial meaning, this difficulty being explicable by the complex nature of the proverbial semantics in general, its imagery, the implicit shades of meaning, and a wide range of potential situations for the usage of the proverb. For this reason dictionary compilers often replace the definition by the description of situations, in which a proverb can be used.

Levin suggested interpreting the meaning of the proverb with a special metalanguage, which could be based on the natural language, or could be symbolic as well as mixed [Levin 1984: 110].

Zhukov stated the principles for interpreting the meaning of proverbs, sayings and proverb-and-saying sentences, asserting that proverbs required different approaches depending on whether they had figurative or figurative and literal meanings [Zhukov 1991: 12-14].

Lomakina worked out the methodology of displaying in a dictionary paremias and phraseological units used by Tolstoy [Lomakina 2016].

From Kotova's standpoint, common proverbs must primarily be the object of paremiography, their frequency being determined by the compilation of the paremiological minimum, based on the sociolinguistic experiment [Kotova 2004: 9, 33]. In the RussianSlavic dictionary of proverbs with English parallels, Kotova gave the degree of proverbial frequency in modern Slavic languages for the first time in multilingual paremiography [Kotova 2000].

Yu. V. Nikolaeva highlighted the importance of corpus research for tracking frequently used proverbs to be included into bilingual dictionaries and multilingual dictionaries of proverbial parallels [Nikolaeva 2000]. The researcher provided convincing arguments concerning the usefulness of the corpus method for avoiding the contradiction between the dictionary as a reflection of the language system and the dictionary as a text-producing tool, obsolete proverbs being easily eliminated from the dictionary with this approach.

In our opinion, modern paremiography can greatly benefit from the postulate of A.N. Baranov and Dobrovol'skij which explains the necessity of reflecting the inner form of phraseological units in their definitions [Baranov, Dobrovol'skij 2008: 190-193]. The extrapolation of this approach to the display of proverbs in dictionaries will make it possible to envelop the total semantics of the proverb and delineate all implications, created by the imagery. 
The elaborated principles of proverbial lexicography were implemented in practice and resulted in the production of sizable dictionaries of Russian proverbs, which were compiled during different periods and numbered among others, those by Zhukov [Zhukov 1991], Zimin and A.S. Spirin [Zimin, Spirin 1996], Kotova [Kotova 2000], Mokienko et al. [Mokienko et al. 2010].

\section{Experimental research}

Experimental research, undertaken by a number of domestic scholars, was aimed to establish the frequency of usage and the degree of comprehension of selected proverbs, which informants displayed. Levin was quite justified in saying that the existence of a proverb in the proverbial fund did not reflect its frequency and required special studies [Levin 1984: 122]. At the same time, the scholar noted that field research was obstructed by the low frequency of proverbs in speech, the inevitably limited selection, which produced statistical errors, and the social stratification of population [Levin 1984: 126].

In the 1970s, an experimental survey was carried out under the supervision of Permiakov, resulting in the compilation of the paremiological minimum, which numbered 1500 Russian proverbs, riddles, omens and other paremias in frequent usage at the time. [Permiakov 1971]. The materials of the experiment and its methodology were subsequently used in research conducted by other scholars.

Kotova, for example, relied on the abovementioned materials and methodology in the development and implementation of the sociolinguistic experiment revealing common Slavic proverbs by means of surveying informants - native speakers of Belorussian, Bulgarian, Polish and several other languages [Kotova 2004]. The impact of Permiakov's experimental work on international paremiology and concurrently the vulnerability of some parameters and results of his experiment were analysed by Mokienko [Mokienko 2010: 14-15].

Experimental research into the understanding of proverbs was conducted by V. G. Didkovskaia and L. A. Petrova [Didkovskaia, Petrova 2014], and some other scholars. The indirect confirmation of the frequent usage of proverbs is supplied by the research, based on modern texts, in particular, media texts, because their authors principally resort to well-known proverbs to realize their purposes of manipulation and influence.

Corpus research [Potapova 2018] can also provide new data about the frequency of proverbs, both diachronically and at the relatively modern period of time.

\section{New approaches}

New approaches to the analysis of proverbs include cognitive and linguistic-and-cultural studies, which have been characterized by intensive development in Russian paremiology during the last twenty years. These approaches were partly prepared by the preceding tradition to analyse proverbs in the context of culture [Kovshova 1999; Teliia 1996, and others] in addition to teaching a foreign language through studies of a country's customs [Vereshchagin, Kostomarov 1990], and partly by the emergence of the new research apparatus, which underwent further development and improvement in the process of its application towards proverbs. The abovementioned remark of Permiakov about the model of the world reflected in proverbs [Permiakov 1970: 20] was further elaborated upon in 
works on the proverbial picture of the world and conceptual/cognitive structures underlying various proverbial groups (cf. [Ivanova 2002], and many others).

Ivanova developed several principles for modelling proverbial concepts and prototypes as well as analyzing the proverb's cognitive structure [Ivanova 2002]. Semenenko explored the cognitive-pragmatic nature of the proverb and elaborated the methodology of the cognitive-pragmatic modelling of paremiological semantics [Semenenko 2011]. The numerous linguistic-and-cultural studies, aimed at delineating the connection between the conceptualization and interpretation of the world in proverbs and the culture of the nation, include works by O. E. Nosova, L. B. Savenkova, A. A. Svitsova and many others [Nosova 2008; Savenkova 2002; Svitsova 2005].

\section{Conclusion}

In view of the above, it is possible to come to the following conclusions:

1. The diversity of approaches to the analysis of proverbs and the multifaceted character of the research are especially apparent when the focus is on works written during the past fifty years. Proverbs were studied in different research paradigms and from different aspects, the views of the leading domestic scholars varied, revealing both common and different features. The differentiation of views on many problems resulted in a deeper and more sophisticated tackling of the controversial points in the theory and practice of proverbial studies.

2. Domestic scholars gave a comprehensive description of structural, semantic and pragmatic properties of proverbs, and elaborated their universal logical-semiotic patterns. Consideration of the proverb in comparison with the other constituents of the paremiological level and the phraseological fund, made it possible to determine the categorical and differentiating proverbial characteristics. An important aspect of proverbial classifications consisted in taking into account the gradual shift from one group of linguistic signs to another, incorporating the variety of features and their similarity in adjacent groups. Important concepts for the typological characteristics of proverbs comprise those of the complete predicative structure, logical-semiotic pattern, "multilayered" semantics, inner form and the quantifier of generality.

3. It is possible to give credit to Russian scholars for not only describing various aspects of the nature of the proverb, but for the thorough studies of the general system of the proverbial fund, the analysis of the paradigmatic relations within it and the implementation of the concept of multi-dimensional proverbial space for modelling the dynamics of these relations. The undertaken studies truly surpass anything done elsewhere in the world and provide useful guidelines for further investigations, based on other languages.

4. The formation and usage of proverbs were analysed in the context of sociohistorical, psychological, cultural conditions and the interaction of various cultures and languages of various nations. Domestic scholars gave both the general description of the pragmatic functions of proverbs and the specific features of their implementation in various genres. Experimental studies launched the research direction that was aimed at identifying the factual usage of proverbs during a certain time period. This helped to bridge the gap between the proverbial fund as a collection of proverbs in potential usage and the actual inclusion of proverbial signs in text and discourse at a very early stage of prolific proverbial studies. 
5. The characteristic features of domestic proverbial studies are that, on the one hand, these studies are based on the achievements of the predecessors and targeted at the implementation of the existing theoretical postulates to the new material, on the other hand, they are in the state of constant intensive development and elaboration, which particularly found its manifestation in the numerous cognitive and cultural-and-linguistic works of the $21^{\text {st }}$ century.

6. Research into the semantic structure of the proverb and the system of the proverbial fund laid the foundations for developing paremiographic principles, resulting in practice in the compilation of diverse dictionaries of Russian proverbs and bi- and multilingual proverbial dictionaries.

\section{Dictionaries}

Zhukov 1991 - Zhukov V.P. Dictionary of Russian proverbs and sayings. Moscow: Russkii iazyk Publ., 1991. 537 p. (In Russian)

Zimin, Spirin 1996 - Zimin V.I., Spirin A. S. Proverbs and sayings of Russian people. Moscow: Siuita Publ., 1996. 544 p. (In Russian)

Kotova 2000 - Kotova M. Iu. Russian-Slavic dictionary of proverbs with English parallels. Dmitriev P. A. (ed.). St. Petersburg: St. Petersburg University Press, 2000. 360 p. (In Russian)

Mokienko et al. 2010 - Mokienko V.M., Nikitina T. G., Nikolaeva E. K. Complete dictionary of Russian proverbs. Moscow: Olma media grupp Publ., 2010. 1024 p. (In Russian)

\section{References}

Amosova 1963 - Amosova N.N. Basics of English phraseology. Leningrad: Leningrad University Press, 1963. 208 p. (In Russian)

Anichkov 1992 - Anichkov I. E. Idiomatics and semantics (Notes for A. Meie, 1927). Voprosy iazykoznaniia. 1992, (5): 140-150. (In Russian)

Anikin 1996 - Anikin V.P. Folklore theory. Moscow: MGU im. M. V.Lomonosova. Filologicheskii fakul'tet Publ., 1996. 408 p. (In Russian)

Apresian 1974 - Apresian Iu. D. Lexical semantics. Moscow: Nauka Publ., 1974. 367 p. (In Russian)

Arkhangel'skii 1964 - Arkhangel'skii V.L. Set phrases in modern Russian. Rostov on the Don: Izdatel'stvo Rostovskogo gosudarstvennogo universiteta Publ., 1964. 315 p. (In Russian)

Arsent'eva 1989 - Arsent'eva E. F. Cross-linguistic analysis of phraseological units. Kazan: Izdatel'stvo Kazanskogo gosudarstvennogo universiteta Publ., 1989. 126 p. (In Russian)

Baranov, Dobrovol'skii 2008 - Baranov A. N., Dobrovol'skii D. O. Aspects of the theory of phraseology. Moscow: Znak Publ., 2008. 656 p. (In Russian)

Cherdantseva 1977 - Cherdantseva T.Z. Language and its images (Essays on Italian phraseology) Moscow: Mezhdunarodnye otnosheniia Publ., 1977. 168 p. (In Russian)

Didkovskaia, Petrova 2014 - Didkovskaia V.G., Petrova L. A. Proverbs and sayings as an object of "naïve linguistics". Vestnik Novgorodskogo gosudarstvennogo universiteta. 2014, (77): 68-70. (In Russian)

Dobrovol'skij 2017 - Dobrovol'skij D. Proverbs and sentential phrasemes of other types. In: Poslovitsy v frazeologicheskom pole: kognitivnyi, diskursivnyi, sopostavitelnyi aspekty. Fedulenkova T.N. (ed.). Vladimir: Izdatel'stvo Vladimirskogo gosudarstvennogo universiteta Publ., 2017. P. 196-204.

Gaevaia 1990 - Gaevaia A. I. Structural and semantic characterization of Russian proverbs with the quality assessment of people. Abstract of the thesis for PhD in Philological Sciences. Moscow, 1990. 16 p. (In Russian)

Gvozdarev 1996 - Gvozdarev Iu. A. Basics of Russian phraseological formation. In: Problemy frazeologicheskoi semantiki. Lilich G. A. (ed.). St. Petersburg: St. Petersburg University Press, 1996. P. 26-128. (In Russian)

Gvozdev 1983 - Gvozdev V.V. The place of proverbs as structural and semantic formations in the language. Abstract of the thesis for PhD in Philological Sciences. Moscow, 1983. 15 p. (In Russian) 
Ivanova 2002 - Ivanova E. V. Proverbial pictures of the world. St. Petersburg: Izdatel'stvo Filologicheskogo Fakul'teta Peterburgskogo gosudarstvennogo universiteta Publ., 2002. 160 p. (In Russian)

Ivanova 2006 - Ivanova E. V. World in English and Russian proverbs. St. Petersburg: St. Petersburg University Press, 2006. 280 p. (In Russian)

Kotova 2004 - Kotova M. Iu. Slavic paremiology. Thesis for D. Sc. in Philological Sciences. St. Petersburg, 2004. 231p. (In Russian)

Kotova, Raina 2020 - Kotova M. Yu., Raina O. V. Towards a linguistic vision of the world at the paremiological level of language. Vestnik of Saint Petersburg University. Language and Literature. 2020, 17 (3): 487-504.

Kovshova 1999 - Kovshova M. L. How to run around with a painted pouch: principals of cognitive and cultural study of idioms. In: Phraseology in the context of culture. Teliia V.N. (ed.). Moscow: Iazyki russkoi kul'tury Publ., 1999. P. 164-173. (In Russian)

Kunin 1996-Kunin A. V. A course of modern English phraseology. Moscow: Vysshaia shkola; Dubna: Feniks Publ., 1996. 381 p. (In Russian)

Lomakina 2016 - Lomakina O. V. Phraseology in the language of L. N. Tolstoi: linguistic comments and lexicographic description. Abstract of the thesis for PhD in Philological Sciences. St. Petersburg, 2016. $42 \mathrm{p}$. (In Russian)

Levin 1984 - Levin Iu. I. Proverbial space. In: Paremiological studies. Permiakov G. L. (ed.). Moscow: Glavnaia redaktsia vostochnoi literatury Publ., 1984. P. 108-126. (In Russian)

Mokienko 1975 - Mokienko V. M. Into the depth of the saying. Moscow: Prosveshchenie Publ., 1975. 175 p.

Mokienko 1986 - Mokienko V. M. Images of Russian speech. Leningrad: Leningrad University Press, 1986. 280 p. (In Russian)

Mokienko 2010 - Mokienko V. M. Modern paremiology (linguistic aspects). Mir russkogo slova. 2010, (3): 6-20. (In Russian)

Molotkov 1977 - Molotkov A.I. Basics of Russian phraseology. Filin F.P. (ed.), Leningrad: Nauka Publ., 1977. 284 p. (In Russian)

Nikitina 1989 - Nikitina S.E. Language consciousness and self-consciousness of a person in folk culture. In: Language and person. Shmelev D. N. (ed.). Moscow: Nauka Publ., 1989. P. 34-40. (In Russian)

Nikitina 1998 - Nikitina T. G. Problems of studying specific ethnic and cultural features of phraseology. Pskov: Izdatel'stvo Pskovskogo gosudarstvennogo pedagogicheskogo instituta Publ., 1998. 204 p. (In Russian)

Nikolaeva - Nikolaeva Iu. V. Corpus method and modern paremiology. https://docplayer.ru/46943745-Korpusnyy-metod-i-sovremennaya-paremiografiya-1.html (accessed: 28.11.2020). (In Russian)

Nikolaeva 1995 - Nikolaeva T. M. Generalization, concreteness and uncertainty in a paremia. In: Malye formy fol'klora. Sbornik statei pamiati G. L. Permiakova. Ivanov V. V. (ed.). Moscow: Vostochnaia literatura RAN Publ., 1995. P.311-324. (In Russian)

Nikolaeva 2000 - Nikolaeva Iu. V. Logical and semiotic peculiarities of Spanish and Italian proverbs. Abstract of the thesis for PhD in Philological Sciences. St. Petersburg, 2000. 20 p. (In Russian)

Nosova 2008 - Nosova O.E. Proverbs and sayings on the role and place of silence (based on the Russian and English languages). Vestnik Bashkirskogo gosudarstvennogo universiteta. 2008, 13 (3): 543-546. (In Russian)

Permiakov 1970 - Permiakov G. L. From a saying to a fairy-tale (Notes on the general theory of cliché). Moscow: Nauka Publ., 1970. 240 p. (In Russian)

Permiakov 1971 - Permiakov G.L. Paremiological experiment: materials for the Russian paremiological minimum. Moscow: Nauka Publ., 1971. 48 p. (In Russian)

Permyakov 1974 - Permyakov G. L. On paremiological homonymy and synonymy. Proverbium, 1974, (24): 941-943.

Permiakov 1975 - Permiakov G. L. To the issue of the paremiological fund structure. In: Tipologicheskie issledovaniia po fol'kloru: sbornik statei. Moscow: Nauka Publ., 1975. P. 247-274. (In Russian)

Potapova 2018 - Potapova N. A. Extraction of paremias with the lexeme "stone" from the texts of the National Corpus of the Russian Language. 2018, 2 (80), 1: 131-135. (In Russian)

Rybnikova 1961 - Rybnikova M. A. Introduction. In: Russkie poslovitsy i pogovorki. Rybnikova M.A. (comp.) Moscow: Izdatel'stvo Akademii nauk SSSR Publ., 1961. P.7-32. (In Russian)

Savenkova 2002 - Savenkova L. B. Russian paremiology: semantic and cultural linguistics aspects. Rostov on the Don: Izdatel'stvo Rostovskogo universiteta Publ., 2002. 240 p. (In Russian) 
Seliverstova 2017 - Seliverstova E. I. The space of the Russian proverb. Stability and change. Moscow: Flinta: Nauka Publ., 2017. 296 p. (In Russian)

Semenenko 2011 - Semenenko N. N. Cognitive-pragmatic paradigm of paremiological semantics (based on the Russian language). Abstract of the thesis for PhD in Philological Sciences. Belgorod, 2011. $46 \mathrm{p}$. (In Russian)

Shadrin 1991 - Shadrin N. L. Translation of phraseological units and cross-linguistic stylistics. Skrebnev Iu. M. (ed.). Saratov: Izdatel'stvo Saratovskogo gosudarstvennogo universiteta Publ., 1991. 218 p. (In Russian)

Shanskii 1985 - Shanskii N.M. Phraseology of modern Russian. Moscow: Vysshaia shkola Publ., 1985. 246 p. (In Russian)

Shvydkaia 1973 - Shvydkaia L. I. Synonymy of proverbs and aphorisms in the English language. Abstract of the thesis for PhD in Philological Sciences. Leningrad, 1973. 20 p. (In Russian)

Sidorkov 2003 - Sidorkov S. V. Proverbial paroemiae as a factor of structural and semantic organization of discourse. Rostov on the Don: Izdatel'stvo Severo-Kavkazskogo nauchnogo tsentra vysshei shkoly Publ. 2003. 214 p. (In Russian)

Svitsova 2005 - Svitsova A. A. Cultural linguistic dominance "Home - Motherland - Abroad" in Russian and English proverbs. Abstract of the thesis for PhD in Philological Sciences. Izhevsk, 2005. 20 p. (In Russian)

Syshchikova 2007 - Syshchikova E. S. Proverbs and sayings in Spanish periodicals. Abstract of the thesis for $\mathrm{PhD}$ in Philological Sciences. Moscow, 2007. 20 p. (In Russian)

Tarlanov 1982 - Tarlanov Z. K. Essays on the syntax of Russian proverbs. Leningrad: Leningrad University Press, 1982. 135 p. (In Russian)

Tarlanov 1993 - Tarlanov Z. K. Language. Ethnos. Time. Petrozavodsk: Izdatel'stvo Petrozavodskogo gosudarstvennogo universiteta Publ., 1993. 222 p. (In Russian)

Teliia 1996 - Teliia V. N. Russian phraseology. Moscow: Shkola “Iazyki russkoi kul'tury” Publ., 1996. 286 p. (In Russian)

Vereshchagin, Kostomarov 1990 - Vereshchagin E. M., Kostomarov V. G. Language and culture. Moscow: Russkii iazyk Publ., 1990. 246 p. (In Russian)

Zhukov 1991 - Zhukov V.P. Introduction. In: Dictionary of Russian proverbs and sayings. Zhukov V.P. (comp.). Moscow: Russkii iazyk Publ., 1991. P.9-21. (In Russian)

Zimin 2017 - Zimin V.I. Explanation of the meaning of proverbs and sayings. In: Proverbs in the phraseological field: cognitive, discourse, cross-linguistic aspects. Fedulenkova T.N. (ed.). Vladimir: Izdatel'stvo Vladimirskogo gosudarstvennogo universiteta Publ., 2017. P.54-68. (In Russian)

Received: November 30, 2020

Accepted: September 13, 2021 


\section{Иванова Елизавета Васильевна}

Санкт-Петербургский государственный университет,

Россия, 199034, Санкт-Петербург, Университетская наб., 7-9

e.v.ivanova@spbu.ru

\section{Об основных направлениях изучения пословиц в отечественной паремиологии}

Для цитирования: Ivanova E. V. On the basic lines of proverbial studies in Russian paremiology. Вестник Санкт-Петербургского университета. Язык и литература. 2021, 18 (4): 875-892. https://doi.org/10.21638/spbu09.2021.415

В статье обобщаются теоретические положения и выводы, сделанные отечественными учеными относительно основных аспектов анализа пословиц и представляющие потенциальный интерес для иностранных исследователей. Один из этих аспектов связан с введением понятия паремиологического уровня языка, что позволило рассматривать его центральную единицу - пословицу - в сравнении со смежными с ней образованиями, обоснованно и целенаправленно выявлять ее категориальные и дифференциальные признаки. Отечественными паремиологами были детально описаны структурные и семантические свойства пословиц типологического и национально-специфического характера, проанализированы сходства и различия пословиц и словосочетаний-фразеологизмов. Большое значение имел анализ системности пословичного фонда и подробные описания парадигматических отношений образующих его единиц, введение понятия провербиального пространства, позволившего рассматривать пословицы в многомерном континууме. Особой значимостью обладали исследования, посвященные значению и внутренней форме пословиц и их взаимосвязи, введение понятия квантора общности и определение характеристик частных пословиц. Важным направлением в исследовании пословиц явилось изучение их прагматических функций и варьирования, реализуемых в тексте и дискурсе, а также анализ знания и использования пословиц носителями языка, основанный на специально разработанной методике экспериментальных исследований. Особого внимания заслуживает обширный теоретический и практический опыт лексикографического описания пословиц. Традиция изучения пословицы в неразрывной связи с культурой и в целом результаты исследования пословичной семантики заложили основы для когнитивного и лингвокультурологического подходов к изучению пословиц, интенсивно развивающихся в последние 20 лет и придающих новый ракурс сопоставительным исследованиям.

Ключевые слова: пословица, паремиология, семантика пословицы, пословичный фонд.

Статья поступила в редакцию 30 ноября 2020 г. Статья рекомендована к печати 13 сентября 2021 г.

* Исследование выполнено при финансовой поддержке РФФИ в рамках научного проекта № 20-112-50028. 